\title{
Adipose Tissue Hypoxia, A Conceptual Alometric View
}

\author{
Marià Alemany ${ }^{\mathrm{a}, \mathrm{b}}$
}

\begin{abstract}
Hypoxia is a condition in which there is an insufficiency of oxygen for normal cell operation. It is directly related to diminished oxygen supply, usually because of restricted/insufficient blood circulation or defective oxygen transport and release. However, in absolute terms, cells in a small size animal may experience hypoxia with an oxygen supply comparable to that of normalcy in larger animals. The question is, essentially, the alometrically-related metabolic rate which translates into the actual individual cell metabolism. Cells in large animals consume less oxygen in vivo than their smaller animal counterparts, but this is not translated into hypoxia in the former. The critical point is not the absolute oxygen supply but the relationship of this to the incorporation of substrates to oxidize. It is the alteration of the ratio between oxidizable substrates and oxygen availability, the factor eliciting the ravages of hypoxia. The normal function of the circulatory system maintains a balanced supply of both terms of the equation; however, substrate oversupply, such as that experienced by adipose tissue in the metabolic syndrome may break the equilibrium, eliciting hypoxia and acidosis, which may derive into inflammation and further cell and tissue damage.
\end{abstract}

Keywords: Hypoxia; Acidosis; Adipose tissue; Inflammation; Metabolic syndrome

\section{Hipoxia, A Relative Term}

Hypoxia is a transient situation in which a given mass of tissue cells does not receive enough oxygen from the blood vessels, i.e. the arterial (assuming a normal oxygen content) blood

Manuscript accepted for publication October 17, 2011

${ }^{\mathrm{a}}$ Department of Nutrition and Food Science, Faculty of Biology, University of Barcelona, Barcelona, Spain, and CIBER Obesity and Nutrition, Institute of Health Carlos III, Spain

bCorresponding author: Marià Alemany, Email: malemany@ub.edu

doi:10.4021/jem52w flow, in $\mathrm{ml} / \mathrm{kg}$ tissue, is not high enough to supply sufficient oxygen (and nutrients), as well as to eliminate excess acidity, carbon dioxide and other excreta [1]. However, the amplitude of margin for most cells in this sense is considerable (except perhaps for neurons). Current theories explaining the effect of size on metabolic rate are based, precisely in higher values for blood flow across tissues in small versus large animals, with cell structures, vascularization, etc. being intrinsically the same. The relationship of metabolic rate as the 0.75 power of body weight [2] shows that the difference in metabolic rate of a $0.25 \mathrm{~kg}$ rat and a $70 \mathrm{~kg}$ man is about $1: 68$. Since the ratio of masses is $1: 280$, the average rat cell is irrigated roughly fourfold than a human cell. Surprisingly, this large difference does not mean customarily that most human cell had to be hypoxic; but a drop in $75 \%$ of oxygen supplied to a rat (i.e. lowering its cells' oxygen supply to human levels) makes them markedly hypoxic and die. The cell structures and oxygen supply may be the same, but there are wide different metabolic consequences derived from organization and, especially, size: size matters. This effect is observed only in vivo, with the cells integrated in a functioning body. Human and rat cells kept in primary tissue cultures do not show significant differences in their consumption of oxygen and substrates; however, if we scale these data to the situation in vivo, the sum of a smaller number of cells in a small animal consumes proportionally more oxygen than the same mass in a larger one, as indicated by the different overall whole body metabolic rate. The obvious explanation is that smaller-animal cells consume oxygen in vivo at a larger rate than those of larger ones; since the metabolic systems are equivalent, the main difference must rely on the side of supply: smaller animal cells receive more oxygen, and the larger animal cells receive less. However, chronic low oxygen supply results in increased angiogenesis [3] and the secretion of erythropoietin [4] to increase oxygenation, but human tissues do not contain a density of capillaries which is different from those of rats [5].

\section{Hipoxia and Acidosis}

Probably the factor determining whether hypoxia becomes a 
problem or not arises not only from the actual oxygen flow into the tissue, but from the parallel interchange of other materials (nutrients, excretion products) of the cells with the interstitial space (and then with blood). Probably $\mathrm{pH}$ is a critical part of the system, since acidosis combined with low oxygen enhances the problems derived from hypoxia [6].

Consequently, hypoxia is essentially a relative term that has to be always considered from the perspective of substrate exchange of a given tissue, operation of its oxidative systems and especially the maintenance of proton concentration. Acidity itself helps free oxygen from oxyhemoglobin [7], and there is a flow of protons between tissues (towards the liver and lung) $[8,9]$ that reduces the need to provide sufficient oxygen to exercising muscle and other tissues under conditions of anaerobic stress [9, 10].

Hypoxia means literally "less oxygen than needed" and anoxia indicates its severe or total absence. When cells do not receive sufficient oxygen, they become acidotic, and die because they cannot use their mitochondrial oxidative machinery to produce enough ATP to sustain their functions (and also because of excessively low $\mathrm{pH}$ generated by exhausting glycolysis). However, we have to distinguish between pure anoxia and lack of blood flow. Evidently, diminished blood irrigation to the tissues provokes hypoxia, but also deprives the cells from receiving glucose and other substrates, and also from excreting carbon dioxide and other catabolites. It also prevents the active exchange of protons with the blood that helps maintain $\mathrm{pH}$ and overall energy homeostasis, including the effect of blood heating/cooling the tissue (thermic homeostasis). Pure hypoxia, however, derives from suffocation or breathing low oxygen-content gas mixtures, i.e. not affecting, at least in an immediate and direct way, the arrival of substrates, the elimination of carbon dioxide and some approximation to the maintenance of $\mathrm{pH}$ (other than those spurned by hypoxia-derived metabolism) and thermal homeostasis.

\section{Blood Flow and Oxygen Supply}

The distinction between decreased blood flow inducing hypoxia and loss of the oxygen content of the blood is of paramount importance. Most mammalian cells (perhaps with the usual exception of neurons, but this is a point that has not been fully investigated) are prepared to live within an ample margin of oxygen supply [11]. This is so because in both cases the arrival of substrates and washing out of excretion products proceed at the same pace as that of oxygen. The critical factor is the balance between availability and needs; it is not, at least to a wide-margin extent, an absolute figure related to cell size, mitochondrial number or other biochemical parameters. The key point is the maintenance of an adequate margin of oxygen concentration in the cell's environment, a condition affected by the flow-in only as it matches consumption.

When oxygen supply is limited overall (i.e. high altitude, increased need (exercise), altered pulmonary function, anemia, etc.) the body tries to compensate the deficit by increasing the flow of blood [10, 12], which also becomes polycytemic and overloaded with hemoglobin to limit the effects of true hypoxia [13]. Cell oxygen concentrations are maintained, but increased substrate consumption provokes an imbalance: increased oxygen demand could not be met, its concentrations decrease and hypoxia limits further energy consumption [14] by compromising the mitochondrial oxidative synthesis of ATP.

In a normally functioning organism, with adequate oxygen supply, and cardio-circulatory and respiratory systems working at a safe pace, leaving a wide margin for increase when needs step up, it is not reasonable to assume that there are significant (and extensive) spots of hypoxia that could not be immediately countered by a physiological response that provides a local marked increase in oxygen supply. It is difficult to maintain true hypoxia in limited areas for long periods, since the lack of both substrates and oxygen elicits the secretion of angiogenic factors that develop new vessels, thus correcting the supply of both $[15,16]$.

In consequence, acute hypoxia occurs only when oxygen demand by the cells is higher than the supply carried by the bloodstream because of: a) insufficient blood flow; b) not enough oxygen carried by a given volume of blood; c) inadequate conditions for oxyhemoglobin freeing its oxygen; or d) exaggerated tissue demand with respect to basal conditions.

Chronic hypoxia, on the other hand is a pathological state consequence of: a) insufficient blood flow due to cardiocirculatory alterations (low heart output, atherosclerosis, hypertension, vascular damage), insufficient tissue angiogenesis and/or high blood viscosity; b) insufficient blood carriage of oxygen due to diminished pulmonary extraction, low hemoglobin, hypovolemia and destruction or lack of red blood cells (anemia); c) difficulties for oxyhemoglobin dissociation (lack of activation cofactors, altered $\mathrm{pH}$, erythrocyte membrane permeability changes, methemoglobinemia, hemoglobins of limited functionality; d) altered blood cell turnover (production and disposal), and regulation of synthesis pathways (erythropoietin), protein, vitamin and essential metal insufficiencies, mainly iron, but also copper and nickel.

The body reacts to chronic hypoxia by a number of compensatory mechanisms that tend to maintain tissue oxygen homeostasis. However, these mechanisms can help aggravate the situation. Increased pressure to raise blood flow can aggravate the problems of hypertension, especially when combined with cell rigidity (implying undeformability) [17], and the polycytemia (resulting in increased viscosity) [18] consequence of erythropoietin activation of red blood cell synthesis [19].

However, even in patients with severe circulatory prob- 
lems, insufficient blood oxygen saturation and altered erythrocyte function, most of the body does not present symptoms of anoxia (except when doing exercise), largely because the metabolic activity is diminished in parallel to the low oxygen supply [20].

\section{Where, Then, and Especially When Hypoxia Occurs?}

In muscle, exercise generates a debt of oxygen higher than the need for substrates [21], since during exercise these are endogenous, at least in a significant proportion [22], and there is a marked production of lactate [23, 24]. In other tissues, with limited internal substrate consumption, at least compared with muscle, the oxygen debt is more limited, but nevertheless occurs with the same effectivity as in occasionally exercising muscle [25].

White adipose tissue energy needs are relatively small, and most of the substrates taken up by WAT are used to build-up its lipid droplet [26], and ATP needs are largely devoted to this task. Adrenergic stimulation such as that of exercise stimulates both lipolysis and glycolysis (the latter mainly from glycogen stores) [27, 28], freeing lactate and protons to the bloodstream [9, 24]. Local acidity increases the dissociation of oxyhemoglobin, freeing more oxygen in a tissue which has little need for it (low ATP needs, sufficient glycolytic-derived ATP, few mitochondria). Altered oxygen supply and the flow of protons may help increase the production, by mitochondria, of superoxide anion and other ROS [29], which in turn can be an accessory component to the development of inflammation [30].

The balance of most cells between their energy substrates and oxygen taken up from the blood are a built in insurance that unless there is an external cause (interruption of blood supply, hormonal signaling) the normoxic status quo will be maintained. Liver, lungs, kidneys and brain are essentially out of this list because of their privileged and massive oxygen (blood) supply. Skeletal muscle activity is largely dependent on oxygen (blood flow) [21] and its export of protons, mainly to the liver [9]. But WAT may be a passive glycolytic organ that receives a limited supply of blood, but which can generate problems (acidity, oxidative stress) under certain circumstances [31, 32].

In consequence, it is probably inadequate to attribute in vivo the ravages of early inflammation in white adipose tissue only to hypoxia [33], since inflammation does not include the expected angiogenic response to hypoxia [33]. The growth of adipose tissue masses require an increased web of vessels which may be promoted by adipocyte (and macrophage) angiogenic factors [34, 35], but the initial cause could not be simply a limited supply of oxygen, but more probably an inadequate blood flow, insufficient to remove excess acidity and to dilute an excess of oxygen-derived free radicals.
Mitochondrial operation may be hampered not only by lack of oxygen as final acceptor of electrons, but also for excessive proton pumping, which in the end may damage the mitochondrial membranes, alter the cytoplasmic redox equilibrium [36] and interfere with calcium and other ion signalling [37]. The action of uncoupling proteins may help protect the integrity of the system [38]. The common use of bicarbonate in intensive care units in situations of anoxia/hypoxia to decrease the $\mathrm{pH}$ also agrees with this interpretation.

In conclusion, the term hypoxia should be used carefully, always describing the context in which it is taken into account, since it is in itself a relative term (i.e. lower oxygen supply than normoxia), and can be experienced at fairly different absolute levels of oxygen supply.

\section{Grant Support}

Supported by grant SAF2009-11739 of the Plan Nacional de Investigación en Biomedicina of the Government of Spain, and by the CIBER Obesity and Nutrition funds.

\section{References}

1. Gutierrez G. Cellular energy metabolism during hypoxia. Crit Care Med. 1991;19(5):619-626.

2. Schmidt-Nielsen K. Energy metabolism. Animal Physiology. Adaptation and Environment. Cambridge: Cambridge University Press; 1975. p. 208-258.

3. Pugh CW, Ratcliffe PJ. Regulation of angiogenesis by hypoxia: role of the HIF system. Nat Med. 2003;9(6):677-684.

4. Ratcliffe PJ, Jones RW, Phillips RE, Nicholls LG, Bell JI. Oxygen-dependent modulation of erythropoietin mRNA levels in isolated rat kidneys studied by RNase protection. J Exp Med. 1990;172(2):657-660.

5. Schmidt-Nielsen K, Pennycuik P. Capillary density in mammals in relation to body size and oxygen consumption. Am J Physiol. 1961;200:746-750.

6. Zhou HZ, Malhotra D, Doers J, Shapiro JI. Hypoxia and metabolic acidosis in the isolated heart: evidence for synergistic injury. Magn Reson Med. 1993;29(1):94-98.

7. Bohr C, Hasselbalch K, Krogh A. Über einen in biologischer Beziehung wichtigen Einfluss, den die Kohlensäurespannung des Blutes auf dessen Sauerstoffbindung übt. Scand Arch Physiol 1904;16:402-412.

8. Latres E, Alemany M, Remesar X. In vivo glucose metabolism in the rat lung. Biochem Arch 1992;8(3):175182.

9. Casado J, Fernández-López JA, Esteve M, Rafecas I, Argilés JM, Alemany $M$. Rat splanchnic net oxygen consumption, energy implications. J Physiol. 1990;431:557-569.

10. Ardévol A, Adán C, Remesar X, Alemany M, Fernández- 
López JA. Muscle blood flow during intense exercise in the obese rat. Arch Physiol Biochem. 1996;104(3):337343.

11. Thomas D. The physiology of oxygen delivery. Vox Sang. 2004;87 Suppl1:70-73.

12. Erzurum SC, Ghosh S, Janocha AJ, Xu W, Bauer S, Bryan NS, Tejero J, et al. Higher blood flow and circulating NO products offset high-altitude hypoxia among Tibetans. Proc Natl Acad Sci U S A. 2007;104(45):1759317598.

13. Reeves JT, Leon-Velarde F. Chronic mountain sickness: recent studies of the relationship between hemoglobin concentration and oxygen transport. High Alt Med Biol. 2004;5(2):147-155.

14. Mador MJ, Bozkanat E. Skeletal muscle dysfunction in chronic obstructive pulmonary disease. Respir Res. 2001;2(4):216-224.

15. Hadjipanayi E, Brown RA, Mudera V, Deng D, Liu W, Cheema U. Controlling physiological angiogenesis by hypoxia-induced signaling. J Control Release. 2010;146(3):309-317.

16. Coleman ML, Ratcliffe PJ. Angiogenesis: escape from hypoxia. Nat Med. 2009;15(5):491-493.

17. Cicco G, Pirrelli A. Red blood cell (RBC) deformability, RBC aggregability and tissue oxygenation in hypertension. Clin Hemorheol Microcirc. 1999;21(3-4):169-177.

18. Wells RE, Jr., Merrill EW. Influence of flow properties of blood upon viscosity-hematocrit relationships. J Clin Invest. 1962;41:1591-1598.

19. Goldwasser E. Erythropoietin and the differentiation of red blood cells. Fed Proc. 1975;34(13):2285-2292.

20. De Blasi RA, Cope M, Elwell C, Safoue F, Ferrari M. Noninvasive measurement of human forearm oxygen consumption by near infrared spectroscopy. Eur J Appl Physiol Occup Physiol. 1993;67(1):20-25.

21. Bangsbo J, Gollnick PD, Graham TE, Juel C, Kiens B, Mizuno M, Saltin B. Anaerobic energy production and $\mathrm{O}_{2}$ deficit-debt relationship during exhaustive exercise in humans. J Physiol. 1990;422:539-559.

22. Henriksson J. Muscle fuel selection: effect of exercise and training. Proc Nutr Soc. 1995;54(1):125-138.

23. Granier P, Dubouchaud H, Mercier B, Mercier J, Ahmaidi S, Prefaut C. Lactate uptake by forearm skeletal muscles during repeated periods of short-term intense leg exercise in humans. Eur J Appl Physiol Occup Physiol. 1996;72(3):209-214.

24. Bangsbo J, Johansen L, Graham T, Saltin B. Lactate and $\mathrm{H}+$ effluxes from human skeletal muscles during intense, dynamic exercise. J Physiol. 1993;462:115-133.

25. DiGirolamo M, Newby FD, Lovejoy J. Lactate production in adipose tissue: a regulated function with extra-adipose implications. FASEB J. 1992;6(7):2405-
2412.

26. Marcelin G, Chua S, Jr. Contributions of adipocyte lipid metabolism to body fat content and implications for the treatment of obesity. Curr Opin Pharmacol. 2010;10(5):588-593.

27. Stich V, de Glisezinski I, Berlan M, Bulow J, Galitzky J, Harant I, Suljkovicova H, et al. Adipose tissue lipolysis is increased during a repeated bout of aerobic exercise. $\mathrm{J}$ Appl Physiol. 2000;88(4):1277-1283.

28. Fredholm BB, Karlsson J. Metabolic effects of prolonged sympathetic nerve stimulation in canine subcutaneous adipose tissue. Acta Physiol Scand. 1970;80(4):567576.

29. Murphy MP. How mitochondria produce reactive oxygen species. Biochem J. 2009;417(1):1-13.

30. Chen B, Lam KS, Wang Y, Wu D, Lam MC, Shen J, Wong L, et al. Hypoxia dysregulates the production of adiponectin and plasminogen activator inhibitor-1 independent of reactive oxygen species in adipocytes. Biochem Biophys Res Commun. 2006;341(2):549-556.

31. Jansson PA, Smith U, Lonnroth P. Evidence for lactate production by human adipose tissue in vivo. Diabetologia. 1990;33(4):253-256.

32. Lee YS, Kim AY, Choi JW, Kim M, Yasue S, Son HJ, Masuzaki H, et al. Dysregulation of adipose glutathione peroxidase 3 in obesity contributes to local and systemic oxidative stress. Mol Endocrinol. 2008;22(9):21762189.

33. Pasarica M, Sereda OR, Redman LM, Albarado DC, Hymel DT, Roan LE, Rood JC, et al. Reduced adipose tissue oxygenation in human obesity: evidence for rarefaction, macrophage chemotaxis, and inflammation without an angiogenic response. Diabetes. 2009;58(3):718-725.

34. Kunduzova O, Alet N, Delesque-Touchard N, Millet L, Castan-Laurell I, Muller C, Dray C, et al. Apelin/APJ signaling system: a potential link between adipose tissue and endothelial angiogenic processes. FASEB J. 2008;22(12):4146-4153.

35. Voros G, Maquoi E, Demeulemeester D, Clerx N, Collen D, Lijnen HR. Modulation of angiogenesis during adipose tissue development in murine models of obesity. Endocrinology. 2005;146(10):4545-4554.

36. Moldovan L, Moldovan NI. Oxygen free radicals and redox biology of organelles. Histochem Cell Biol. 2004;122(4):395-412.

37. Wu Z, Zhang J, Zhao B. Superoxide anion regulates the mitochondrial free $\mathrm{Ca} 2+$ through uncoupling proteins. Antioxid Redox Signal. 2009;11(8):1805-1818.

38. Negre-Salvayre A, Hirtz C, Carrera G, Cazenave R, Troly M, Salvayre R, Penicaud L, et al. A role for uncoupling protein-2 as a regulator of mitochondrial hydrogen peroxide generation. FASEB J. 1997;11(10):809-815. 